\title{
The Limits of Foreign Authority: Publicity and the Political Logic of Ambivalence in Postwar Bosnia and Herzegovina
}

\author{
ANDREW GILBERT \\ Anthropology, McMaster University
}

In January of 2000, a group of four Sarajevo-based intellectuals put forth a bold and controversial proposition in the weekly magazine Dani (Pečanin et al. 2000). Citing the active obstruction of the functioning of the state by the political classes of Bosnia and Herzegovina, and seeing no way out of this situation within the political framework created by the Dayton Peace Agreement, they called for Bosnia and Herzegovina to be established as a full protectorate of the international community for one year. They directed their appeal at Wolfgang Petritsch, then seven months into his tenure as Bosnia and Herzegovina's international overseer, or High Representative (HR). They called upon him to exercise the considerable powers at his disposal to suspend all parliamentary bodies at all government levels as well as the presidency of the state, and assume their powers himself; to make all official institutional and administrative bodies in Bosnia and Herzegovina part of the administration of the Office of the High Representative (OHR); to postpone the elections planned for later that year; to reorganize domestic military forces in Bosnia and Herzegovina;

Acknowledgments: This article benefited from the questions and comments I received wherever I had the privilege of presenting this research, including the Reppy Institute for Peace and Conflict Studies at Cornell University, the Anthropology Department Colloquium at CUNY Graduate Center, the Political Science Departmental Colloquium at McMaster University, and the Centre for South-East European Studies at the University of Graz. Particular thanks go to participants in the workshop "Towards an Anthropology of International Intervention" at McMaster University, which was generously supported by a Wenner-Gren Foundation grant. I also thank Andrea Muehlebach, whose generous feedback on multiple drafts benefitted the article significantly. Above all, I thank Andy Graan who has been a crucial intellectual companion through many iterations of this article, and whose own work on foreign publicity initially inspired the analysis I develop here. I am also grateful to the anonymous $C S S H$ reviewers, whose suggestions helped me to clarify the stakes of the article. Research for this publication was financially supported by the International Research and Exchanges Board and the American Councils for International Education. 
and to reconstitute domestic governmental administration to fit the requirements for membership in the European Union.

Their proposition was not as far-fetched as it might first appear. Years of international intervention had already significantly shaped postwar politics in Bosnia and Herzegovina. Comprising an uneasy encounter between and among Bosnia and Herzegovina political classes and a wide array of foreign agencies like the one headed by Petritsch, these interventions ranged from indirect relations of supervision to the direct participation of foreign agents in Bosnian government. Indeed, Petritsch and his predecessors in the OHR had often exercised their power in ways usually associated with state government, such as creating a common currency or promulgating property legislation. They had also exercised it in extraordinary ways, such as by removing the duly-elected president of Bosnia's Republika Srpska (RS) from office.

Moreover, most analysts and commentators recognized political dysfunction in postwar Bosnia and Herzegovina as rooted in its multiple, contradictory, incomplete state-building projects, all of which turned on differing definitions of the self-determining polity: mono-ethnic, multi-ethnic, or non-ethnic. These projects were all products of the 1990s war and were partially legitimized and institutionalized by the internationally brokered Dayton Agreement; all Bosnia and Herzegovina politicians staked their legitimacy on being proponents of one or another state project. This situation subordinated all domestic political and legislative questions to a calculus of which vision of the state they would support or undermine. For many observers, the unfinished nature of the state was thus a recipe for political paralysis.

The provocation of the four intellectuals thus simply took the already existing powers of Petritsch's office and the paralysis of the war and postwar intervention to its logical conclusion: They sought to compel Petritsch to dispense with all pretense of democracy by abandoning what, for them, was the halfway and halting exercise of his powers. They demanded that he instead act decisively to create the framework for democratic government, settle the question of the state, and thereby sideline the forces of obstruction.

Petritsch publicly responded to their provocation with an argument that reflected the very ambivalence and hesitation which the proposition's authors repudiated. In his reply (OHR 2000a), also published in Dani, Petritsch rejected international responsibility for Bosnia and Herzegovina's political paralysis. He argued for patience in building democracy, while acknowledging deficiencies among Bosnia and Herzegovina's politicians, who "lacked responsibility," as well as its citizens, who "lack political maturity." It was precisely in the interests of the twin goals of building democracy and an independent state that he ruled out a protectorate: "People will only learn how to run their country when they are given a chance to do it by themselves. In Bosnia and Herzegovina, even the limited powers of the High Representative have led to a certain culture of dependency. A protectorate ... would subjugate Bosnia and Herzegovina's 
society and structures and make it impossible for them to ever become independent and self-sustaining. For the International Community, a protectorate would be a commitment with no end in sight."

Framed within a discourse of "local ownership," Petritsch argued that the state had the task to "become stronger and legitimize itself by offering its citizens real values," and that its citizens were obliged "to accept the state as their home country and work on making it comfortable." It was the political classes and the citizenry of Bosnia and Herzegovina that had the primary responsibility for solving the country's problems. At the same time, he expressed sympathy with the frustration of the authors and noted that there were occasions when circumstances required him to abandon his passive, supervisory position. Thus while "the process must be led and conducted by the people of Bosnia and Herzegovina," he was not above exercising his powers to create a framework that would help that process along:

There are laws that each state simply needs, and I am willing to impose them if a majority of parliament members are not capable of doing it themselves. I have zero tolerance for obstructionists and nationalists and consider them poison for this country; I will continue to use my powers against them. There are issues of such importance that I will do whatever I can to further them - such as economic reform, growth and job creation, such as refugee return and the Rule of Law. My goal is to establish a framework that will give the officials and citizens a chance to act responsibly and take their fate into their own hands. It is up to them to seize this opportunity.

It might be tempting to brush aside the provocation of these four intellectuals as unrepresentative or unserious, or to see Petritsch's attempt to disavow his role in shaping the state of Bosnia and Herzegovina politics as disingenuous. It is hard to overlook the inconsistency between the claim to promote "local ownership" by Bosnian politicians and citizens while at the same time regularly imposing laws outside of the legislative process. Yet I open this article with this public demand and ambivalent disavowal because they perfectly exemplify two means/ends contradictions common to post-Cold War international intervention (Heathershaw 2012; Paris and Sisk 2007; Toal and Dahlman 2011; Zaum 2012): a democratization paradox of "imposing democracy," that is, promoting democratic ends through undemocratic means, and the state-building paradox of building an independent state by violating the principle of popular sovereignty that underwrites the UN model of national selfdetermination. The exchange between Petritsch and the intellectuals also illustrates a crucial strategy through which Petritsch sought to pursue his goals

\footnotetext{
1 All of the quoted material from anyone representing the OHR is taken, in English, from the OHR website (including those that appeared in Bosnian news media, such as in Reporter, Dani, or Nezavisne Novine). It was a regular practice of the OHR press office to supply both English and local-language versions of any form of publicity that featured a member of the OHR. All other quoted media material from Bosnian into English is my own translation.
} 
despite these contradictions, and exemplifies a widespread but understudied form of political communication that is shaping and limiting the effects of nation-building intervention in the twenty-first century.

Contradiction and ambivalence also mark the ways in which Bosnia and Herzegovina has entered the foreign policy lexicon as a post-Cold War case study against which to measure future and impending actions, from Kosovo and Iraq to Afghanistan and Syria. When Bosnia and Herzegovina is held up as a model it is because of the absence of conflict since the Dayton Peace Agreement was signed; its internationally brokered, decentralized form of powersharing government is praised as a way to accommodate ethnically defined warring parties within a single state form. When Bosnia and Herzegovina is held up as a warning, it is usually because of the duration, cost, and unrealized ambition of the postwar intervention, and the fact that two decades after the end of war the people of Bosnia and Herzegovina do not share a unified vision for the country as a whole. These wider foreign policy discussions about the lessons of Bosnia illustrate that there is little consensus on what constitute the obligations and responsibilities of intervention aside from a commitment to existing nation-state borders: Is it merely the absence of war? Ensuring a functioning legal order, or a united, self-governing, and democratic polity? The exchange between Petritsch and the Bosnian intellectuals suggests that, in important ways, such obligations and responsibilities are the mediated outcome of the intervention encounter itself. This article offers a case study in that mediated production by focusing on a crucial site of political engagement - mass-mediated public culture - that has been largely overlooked in studies of international intervention.

I draw upon the Press and Public Information archive of the OHR, together with Bosnian news media documents, to investigate and describe the OHR's practices of publicity or being-in-public, where engagement took place in press releases and press conferences, broadcast interviews, and published letters. Such analysis restores a sense of the dialogic nature of international intervention, the ways in which powerful figures like Petritsch and a range of both domestic and foreign actors were forced to contend with one another's speech and action as they pursued their various goals. It demonstrates how Petritsch's contradictory positions forced him to innovate, as did the fact that he had to pursue his aims according to a timeline, events, and cultural materials not of his choosing. It locates important limits to foreign-instigated transformation in the performative requirements, entanglements, and interdependencies produced as locals and foreign agents tried to put one another into the service of their political projects. I offer, then, a view of international intervention that sees it as more volatile, open-ended, and unpredictable than do either the ordered and formulaic representations of the technocratic vision (Gilbert 2012) or the critiques (and celebrations) which confidently cast international intervention as a form of (neo)imperialism (Chandler 2006; Ignatieff 2003; Knaus and Martin 2003). 
First and foremost, an analysis of OHR publicity reveals ambivalence as a political logic of intervention. This is ambivalence not in the sense of uncertainty or indecisiveness, but in the sense of occupying a position that must simultaneously accommodate demands that pull in opposite directions, or reconcile rationales for action that appear contrary. Rather than ignore or seek to overcome the two normative contradictions of his position, I show how Petritsch sought to legitimize his perspective and actions in ways that both sustained the norms of democracy and sovereign statehood that he advocated, as well as suspended the contradictions behind how he promoted them. This allowed him to argue that the use or non-use of the quasi-sovereign powers at his disposal were something other than arbitrary decisions, while also retaining a broad range of pragmatic responses to the vagaries of Bosnia and Herzegovina politics as he pursued the goal of political transformation. In discursively stabilizing the ambivalence of his position, Petritsch relied upon and reproduced an image of postwar Bosnia and Herzegovina as caught in a transitory temporality, a temporary state of exception to the normal nation-state order of things. ${ }^{2}$

Operating according to a logic of ambivalence afforded Petritsch a calculated flexibility to tack back and forth between various positions of legitimacy and authority. This became clearest in the way he shifted between different voicings and positions in the circuit of communication described in democratic theory of the public sphere (Fraser 2007; Habermas 1989). At times, such as in the exchange in the pages of Dani, he occupied the position of the addressee of local public opinion, a representative of state-like power responding to being called upon to act. By sometimes occupying the position of addressee, he could take up a position as an articulator of some element of Bosnian public opinion, voicing demands on Bosnia and Herzegovina politicians for particular legislation or official accountability. However, Petritsch also created additional circuits of communication when he occupied the position of the addressee of international opinion, responding to being called upon by the international community to act. At times, when making demands of Bosnia and Herzegovina politicians he positioned himself as an articulator of international opinion. ${ }^{3}$

\footnotetext{
2 Positing a state of exception to nation-state forms of territorialized sovereignty has led some to see international intervention as a form of (neo)imperialism (Chandler 2006; Duffield 2007; Gregory 2004). Giorgio Agamben (2005) has been influential in this regard. Drawing upon the writing of Carl Schmitt, he argues that to declare a state of exception to the usual (constitutional, lawful) order of things is to stand outside of that order, and may be the ultimate sign of sovereign power itself. I am less interested here in inquiring into the sovereign status of the OHR or Bosnia and Herzegovina than I am in exploring what we might call a situation of "normative stress," when someone (like Petritsch) tried to maintain a norm (like that of sovereign statehood) under circumstances that seem to make that impossible.

${ }^{3}$ It is part of my argument that the political logic of ambivalence was the product of the contradictory position of the OHR. Thus, although I focus mostly on events when Wolfgang Petritsch was HR, I occasionally include examples of OHR publicity from when others occupied that position.
} 
In other words, he used publicity to generate multiple positions of legitimacy by defining and delineating the sources that he claimed authorized his speech and action ("the people," "the international community"), as well as his relationship to these sources. This reflects a broader point of speech act theory found in other studies of the mass media's role in the practice of international politics, namely, that repetitive, iterative, and citational discursive practices have a performative capacity to constitute the objects of which they speak (see Dodds and Carter 2014 on film; Dodds 1996 on political cartoons; and Robison 2004 on print media). ${ }^{4}$ Such discursive practices do not exist in a vacuum, however, but in dialogue with and against similar practices carried out by a range of others. In fact, the majority of OHR publicity was animated by the instabilities created by operating according to a logic of ambivalence. In this article, I trace three of these.

The first instability was illustrated by the opening exchange: exercising state-like powers and claiming to do so in the interests of a Bosnia and Herzegovina public made him an addressee for demands like those made by the intellectuals. This compelled Petritsch to define and delimit the relations of representation that he generated by acting in the name of others, and thus limit the obligations that they entailed. A second instability created by the movement between these positions of authority was that his ability to occupy them both was contested; the claim that he was motivated by or aligned with some representation of "the people" in Bosnia competed with many others doing the same thing. He operated with an obvious legitimacy deficit as an unelected foreigner whose position stood outside of Bosnia and Herzegovina's constitutional order. Petritsch responded by using publicity to summon and perform relations of accountability outside of those institutionalized in processes like elections. He also utilized the OHR press office to circulate and monopolize the authorizing discourses of democracy and Europe in ways that deflected the democratization paradox.

A final instability was related to the transitory temporality that underwrote the logic of ambivalence, the claim that the disorder of postwar politics made the powers of the OHR necessary but exceptional. By itself, such an argument was a claim seeking evidence and bestowed upon Petritsch the obligation to demonstrate that he was working to overcome this disorder and end the state of exception, thereby ushering in political relations that followed the norms of the nation-state order and making his position obsolete. Publicity was thus also part of an effort to call forth "responsible government" with the will to carry out necessary reforms. Toward this end, Petritsch orchestrated enactments

\footnotetext{
4 In part, it is because of the public sphere's role as a privileged site for conjuring the mass abstractions of normative democratic theory and national self-determination, such as "the people," "the general interest," and "public opinion" (Anderson 1991; Fraser 2007; Habermas 1989), that it came to be a dominant space where the stagecraft of statecraft played out.
} 
of "democracy-at-work" or "local ownership," which in order to be persuasive needed the active participation of elected officials as the privileged representatives of the popular will. And that participation could not be taken for granted.

This opens up new insights about the performative dimension of international intervention. Others have written about how, in contexts of international intervention, abstractions like "security" are best understood through the embodied performances and enactments that constitute them (Bialasiewicz et al. 2007; Higate and Henry 2009). Jeffrey has further shown that internationally instigated performances can stabilize particular state ideas in the contentious environment of postwar Bosnia and Herzegovina (2013). What these studies leave unexplored, however, is whether, how, or why such enactments or performances succeed or fail. I raise these questions by pointing out how performances of "democracy-at-work" or "local ownership" were initiated to create a persuasive evidentiary basis for claims to legitimacy and authority. In doing so, I show how publicity was a site not only where such performances were orchestrated, but also where various actors sought to define, circulate, and contest the criteria for evaluating their success or failure. The third instability created by the logic of ambivalence was related to the performative realizations necessary to collapse the temporal state of exception.

Attempts by Petritsch to end the state of exception by inciting Bosnian elite participation in acts of "local ownership" show that mass communication can work as a technology of governmentality, an instrument to shape "the conduct of conduct" and "to control the possible field of action of others" (Foucault 2002: 341; see also Graan 2016). Indeed, OHR publicity was replete with "tactics of education, persuasion, inducement, management, incitements, motivation, and encouragement" (Rose and Miller 1992: 273; see also Inda 2005) that sought to shape the will, desire, and calculations of Bosnian political elites. And yet, such attempts can be quite difficult to pull off. ${ }^{5}$ Indeed, events of "democracy-at-work" or "local ownership" became occasions for Bosnia and Herzegovina politicians to stage enactments of their own authority and legitimacy, enactments that also reveal a set of ambivalent tensions. On one hand, these politicians sought to demonstrate that they could gain and maintain international recognition, an important currency in domestic politics. On the other, the requirements for international recognition could undermine core selfauthorizing discourses, such as that of "national self-determination." Bosnian politicians thus also operated according to a logic of ambivalence, and

\footnotetext{
5 In a study that can be read fruitfully alongside this article, Graan (2016) offers an advanced theorization of the communicative dimensions of governmentality through an analysis of foreign publicity in post-conflict Macedonia. While he does recognize the limits of foreign publicity as a form of governmentality, his analysis emphasizes instead the pervasive and often subtle effects that this form of public diplomacy had on Macedonian politics, even if it might have failed in specific instances.
} 
developed their own discursive and pragmatic strategies to manage the political risks and rewards of the intervention encounter.

After examining the three instabilities that demonstrate the promise and risk to operating according to a logic of ambivalence, I conclude with a reflection on the ways in which a focus on publicity opens up unique insights regarding the political dynamics and limits of nation-building intervention. The last few decades have shown that the UN nation-state model remains the normative form for collecting (and limiting) political will and containing conflict (Kelly and Kaplan 2009), and that the language and rituals of representative democracy hold strong attraction for interveners and local political actors alike. And yet, as Borneman has observed, despite what may appear to be a nearly global consensus about the language of democracy, this is not matched by any "cross-cultural agreement" on the particulars, "on what might constitute an adequate system of 'representation,' or what power is actually being yielded in a 'delegation of authority,' much less to speak of principles of 'popular will' or 'majority rule"' (2003: 37). He concludes that "democratic arrangements will always be historically contingent, varying greatly by region and place, by local forms of power and authority" (ibid.). By focusing upon publicity as a site and instrument of international intervention, this article provides an example of just such a "democratic arrangement" in the making. It exposes critical and empirical blind spots that come with framing international intervention as a form of transnational hegemony or (neo)imperial domination, and offers an example of how the effects of what is projected to be a temporary state of exception can accumulate and gain a durability that ultimately make that exception unsustainable.

THE INTERNATIONAL COMMUNITY AND STATE-BUILDING IN POSTDAYTON BOSNIA AND HERZEGOVINA

From at least the disintegration and dismemberment of Yugoslavia in the early 1990 s, the existence and legitimacy of state form in the Balkans has depended in part upon the recognition by powerful European states and thus upon the ability of domestic officials to fulfill the requirements for such recognition. ${ }^{6}$ The status of Bosnia and Herzegovina's various state-building projects has been a matter of foreign mediation since the recognition of its independence by the European Commission, which touched off its bloody war. This recognition politics continued through the war in the jockeying for international public opinion and foreign approval in international negotiations over what Bosnia and Herzegovina's postwar state form(s) might be, and culminated in the Dayton Agreement.

\footnotetext{
6 See Cowan 2007 for a longer history of such requirements in the Balkans, and Howland and White 2009 for a wider discussion of the recognition doctrine that has guided the admittance of new states into the UN.
} 
This origin of the current state of Bosnia and Herzegovina with the Dayton Agreement - a political agreement to secure an end to war rather than to institute a new social contract or state order-likely accounts for the ways in which it cobbled together and gave partial legitimacy to the multiple, contradictory state-building projects of the war. The unstable nature of Bosnia and Herzegovina's state form has made the cultivation of good relations with powerful states and international institutions, or at least their recognition of one's authority, a continuing priority.

Formally, postwar Bosnia and Herzegovina is a complex, politico-juridical unit: the State of Bosnia and Herzegovina is made up of two political "entities," the RS and the Federation of Bosnia and Herzegovina, with the latter further divided into cantons. Different governmental competencies exist at each level, with the majority clustered around the entity in the RS, and divided between the entity and the cantons in the Federation. The state level created by the Dayton Agreement included a ceremonial tri-partite presidency, a constitutional court (that included non-Bosnian judges), a parliament, and ministries with only minimal responsibilities such as diplomatic affairs and monetary policy. Reflecting the principle of multi-ethnicity, these state institutions were organized around a "national key," requiring an equal division of posts to be occupied by Serbs, Croats, and Bosniaks. ${ }^{7}$

The RS is a mono-ethnic state project founded on the European model of national self-determination, and is made up of a territory that at the end of the war had been largely "cleansed" of its substantial non-Serb population. Bosnian Serb political elites from the RS tend to be hostile to the state level of government and to pursue maximal independence for the RS.

The Federation is the result of the 1994 Washington Agreement, an internationally mediated settlement for peace between Bosnian Croat forces and the Army of the Republic of Bosnia and Herzegovina that recognized an ethnic division of territory into cantons, most of which were either Bosniak-majority or Croat-majority. Bosniak political elites tend to advocate a single multi-ethnic state and thus pursue a strong state level, while Croat political elites tend to pursue a strong entity and cantonal system, or to advocate for a third, Croat-only entity modeled on the RS. All politicians sacralize their state projects by pointing to the blood spilt in the 1990s war.

For their part, international authorities have tended to advocate a multiethnic unified nation-state and have sought to strengthen the central state government by arguing that this state form was necessary for membership in panEuropean institutions like NATO and the EU.

\footnotetext{
${ }^{7}$ I use the terms Bosniak (Bošnjak) and Bosnian Muslim (Musliman), along with their adjectival forms, interchangeably, as most of my interlocutors did. That said, when quoting or reporting speech, I render the terms as they were given.
} 
The question of Bosnia's status as an international protectorate was not envisioned when the High Representative position was created by the Dayton Agreement. As the international agent mandated to oversee the implementation of the "civilian aspects" of that agreement, it was originally conceived to play a temporary mediating role. Still, Dayton did make the HR position "the final authority in theatre regarding interpretation" of those civilian aspects. The boundaries of what that interpretive authority entailed were further determined and elaborated by the Peace Implementation Council, an international body that was established after the completion of the Dayton Agreement.

It was initially foreseen that the HR would only need to play its coordinating role between the parties to the Dayton Agreement for about a year. That was revised when it became clear that many of those parties had no intention of abiding by its terms. The first HR, former Swedish Prime Minister Carl Bildt, found himself powerless when Bosnian politicians, hostile to the Dayton state form and its multi-ethnic principle of government, deliberately blocked the functioning of state institutions and ignored key provisions of the Dayton Agreement. A critical moment in the expansion of the HR's powers came at a December 1997 Peace Implementation Council meeting in Bonn in which the Council welcomed "the High Representative's intention to use his final authority in theatre regarding interpretation of the Agreement ... in order to facilitate the resolution of difficulties by making binding decisions, as he judges necessary" (Peace Implementation Council 1997). The exercise of this authority became known as the "Bonn powers" and with them the HR could now: remove officials, including democratically elected politicians, from public office and ban them from future government roles; impose legislation; and take other measures including executive decisions and financial sanctions. Behind the Bonn powers stood an NATO-led military force and UN police force ready to back up any decree made by the HR.

The first use of the Bonn powers by the then HR, Spanish diplomat Carlos Westendorp, was to impose the basic building blocks of a common state: a citizenship law, flag, national anthem, currency, and license plate system. Having thus established a precedent linking Bosnian statehood to the presence and power of the international community, Westendorp turned to the other area critical to realizing the goal of common statehood: the return of refugees to their prewar homes, a process that had the potential to reverse the effects of ethnic cleansing. This exemplified and cemented the international community's commitment to a political and moral order in Bosnia and Herzegovina premised on the reality of ethnic groups and their coexistence on Bosnia and Herzegovina territory.

The expanded use of the Bonn powers was paralleled by expanded use of publicity $^{8}$ and expanded intervention into the broadcast and print media

\footnotetext{
${ }^{8}$ For example, press releases went from around fifty in 1996 to 275 in 2001; press conferences increased from just a handful in the early years to sixty-two in 2002; interviews given or articles
} 
sphere. ${ }^{9}$ This was not only true of the OHR, but also other international actors in Bosnia; indeed, the presence of foreigners in Bosnia's mass media was ubiquitous. In his exceptional analysis of international oversight and foreign publicity in post-conflict Macedonia, Graan (2010) describes the ways in which foreign speech in the Macedonian public sphere was dominated by registers of expertise and evaluation. This is an apt characterization of the international presence in Bosnia and Herzegovina news media: no matter what the immediate issue being reported upon, foreigners routinely used these occasions to offer evaluations of Bosnia and Herzegovina politics and society, of its past, present, and future. Bosnia and Herzegovina politicians were also routinely asked for their reaction and commentary on such foreign evaluations, which animated further replies by foreign officials. All of this was fodder for Bosnia and Herzegovina's commentariat and everyday conversation. The ubiquity of such assessments helped account for the widely held notion, shared by international and domestic populations alike, that Bosnia and Herzegovina politics hinged to a greater or lesser degree on the power of outside forces and the recognition they could bestow or withhold.

FOREIGN PUBLICITY AND THE POWER OF THE HIGH REPRESENTATIVE

The HR's use of publicity followed a logic of ambivalence as he worked to legitimize his actions in ways that sustained the norms of democracy and sovereign statehood that he advocated, while suspending the contradictions behind how he promoted them. In what follows, I illustrate this politics of ambivalence by delineating the multiple participant roles that Petritsch invoked and through which he developed a calculated flexibility to tack back and forth between various authorizing positions. As suggested above, occupying these various positions created opportunities that he sought to take advantage of, and instabilities that he sought to manage, by calling upon different authorizing discourses. I thus also briefly touch upon the OHR's use of each of these discourses, all the while keeping in mind the ways in which the public sphere was a political field of struggle and competition.

One authoritative position was as a representative of the "international community." Here the OHR's use of publicity accomplished what Bourdieu (1991) described as the power of spokespersons, those individuals whose

published went from fourteen in 1996 to seventy-four in 2001; and speeches from thirteen in 1996 to fifty in 2002. This period also saw the expanded use of public information campaigns, including posters and billboards, paid advertising, and the foreign sponsorship of television and radio programming.

9 Although space prevents me from detailing it here, there is a parallel story to be told about forceful foreign intervention into the field of broadcast and print media licensing and regulation, ownership, and programming, and investment in and control over infrastructure. Much of this story has been told in Ahmetašević 2012; and Price 2002. 
authority is delegated by those they represent. Bourdieu points out that spokespersons effectively create the group that they claim to speak for-they evoke such groups as they invoke them as a source of authority. In important respects, the power of the HR was linked to the "international community," an amorphous yet powerful abstraction that he brought into being precisely by constantly invoking it, and his relationship to it, in public through his speech and actions. These actions could include orchestrated meetings with ambassadors and visiting foreign ministers, speeches at the UN General Assembly, or regular reports to the Peace Implementation Council, all duly reported by the OHR Press Office and circulated by Bosnia and Herzegovina's mass news media.

As a representative of the international community, he could take one of two authorizing positions. The first was that he could articulate international opinion when making demands of Bosnia and Herzegovina officials, offering the benefits of international recognition or the sanction of international disapproval: "My Office and the international organisations operating in Bosnia and Herzegovina will continue to insist on progress and an improvement in the lives of the country's citizens.... The international community is on the brink of losing interest in Bosnia and Herzegovina. The honeymoon is over for good. If we do not achieve a decisive breakthrough in 2001, Bosnia and Herzegovina will find itself on the outskirts, but not part of European wealth and prosperity" (OHR 2000f).

Alternately, he could position himself as an addressee of international opinion, legitimizing his actions as a response to demands made upon him: "I did not dismiss 22 officials because I wanted to punish anyone.... I did it because it is becoming increasingly difficult to explain to the representatives of the outside world, who pay for the peace process in Bosnia and Herzegovina, why people who blatantly violate laws and the Dayton Peace Agreement, who stamp on citizens' rights, hold positions here" (OHR 1999).

However, various HRs conceived of their power as also linked to their ability to speak and act according to the interests of the people(s) of Bosnia and Herzegovina. This is the second set of relations of authority and accountability that Petritsch sought to conjure and demonstrate through his use of publicity. The claim to act according to the interests of the population of Bosnia and Herzegovina was often demonstrated when he responded as an addressee of their desires and demands, such as in an open letter to pensioners: "Dear Pensioners, As the winter is knocking at Bosnia and Herzegovina's door, my office is flooded with letters from you, worried that you will not have enough money for food, medicines or heat.... I understand your concerns" (OHR 2000e).

Or take the example of a speech delivered by Petritsch in early November 2000 (OHR 2000d), in which he argued that citizens should vote in an upcoming election. One way he cultivated a sense of accountability with an undifferentiated Bosnian public was to directly articulate the contradiction behind such 
a call to vote coming from him: "Do the powers of the High Representative make a mockery of the whole elections process ... [when laws] can be imposed whenever he or she wishes it?" In his response, he repeated that his powers were necessary because of the transitory temporality that Bosnia and Herzegovina inhabited - "extraordinary powers for an extraordinary time"while professing his goal to see Bosnia and Herzegovina return to an ordinary time when his presence would no longer be needed. Until that happened, he would be ready to exercise his powers but foregrounded this as part of his responsibility to the international community; at the same time, he also noted that that was "cold comfort to the Bosnian citizen." His speech made its points dialogically by commenting upon a series of strips by the cartoonist for Dnevni Avaz, a prominent Sarajevo-based daily newspaper. Not only did this perform a kind of accountability as the addressee of a Bosnian public opinion critical of the OHR, but it also gave his response to such critiques a kind of cultural authenticity as a co-participant in the Bosnia and Herzegovina public sphere.

As an addressee of Bosnian desires and opinion, he could switch to take the position of an articulator of the population's interests, such as when he addressed non-Bosnian audiences in speeches outside of the country. More importantly, however, taking the position as an articulator of the interests of an undifferentiated Bosnia and Herzegovina public, or one or another of Bosnia and Herzegovina's ethnically defined peoples, allowed him to dispute Bosnia and Herzegovina officials doing the same thing. This was particularly important when he acted against them, such as when he removed the Ante Jelavić from his position as a member of the Bosnian Presidency: "Mr Jelavic is not concerned about the well-being and position of the Croats, the people he allegedly represents, but only the well-being and position of extreme nationalists and perhaps even criminal elements in his party.... This is of course not what I want. I want the Croats of Bosnia and Herzegovina to participate in the improvement of conditions here-economic, social and cultural conditions. I will not allow only a few to get richer and richer, while ordinary people are left behind" (OHR 2001b).

\section{Discourses of Europe and Democracy}

While tacking back and forth between these participant roles, the HR also used publicity to deploy the authorizing discourses of Europe and democracy and thereby to monopolize the ability to define what was democratic or European. Indeed, many OHR statements emphasized Petritsch's role in mediating Bosnia and Herzegovina's movement towards its inevitable European future and contextualized his perspectives and actions as aligned with "Europe" and its attendant positive features: wealth, modernity, democracy, civilization, and normality (see Majstorović 2007). He thus often sought to legitimize his criticism and punitive actions by pointing out the un-European nature of others' 
actions or inactions. For instance, in his decision to remove the Federation minister of finance from his position, the HR argued that he had to act because the minister, in the face of a significant scandal, had failed to do "what is expected of any Minister of Finance [found in the same position] in Europe" (OHR 2002c). Elsewhere, in assessing a vote taken in the Federation Parliament that went contrary to what he had called for, the HR declared "Bosnia and Herzegovina will not be able to get into Europe with the current arrangements" (OHR 2003). Through this Europeanization strategy various HRs downplayed the exercise of the Bonn powers by deflecting the contradiction surrounding the means of "imposing democracy" by emphasizing the inherent good of the ends of Europe.

A second and overlapping practice was to invoke the discourse of liberal democracy. Much like the Europeanization strategy, democracy was presumed to be a state of being that Bosnia and Herzegovina had yet to achieve, but one for which there was also no alternative. OHR publicity would thus regularly stage impasses that required international action to break. In this way the HR often justified his impositions of law or removals of elected officials as necessary by pointing to the illiberal nature of and failed democratic relationship between the people of Bosnia and Herzegovina and their political representatives-Bosnia and Herzegovina's politicians were failing to act democratically and Bosnia and Herzegovina's citizenry was failing to hold them accountable. By maintaining the ability to shift between various authorizing positions, and investing his perspectives and actions with the values of Europe and democracy, he could project an alignment between the desires of a Bosnian public and an authorizing international community.

\section{Discourse of Evaluation}

Tacking between these authorizing positions, however, also created a set of instabilities and vulnerabilities. For example, Petritsch's claims to act in the name of the people(s) of Bosnia and Herzegovina came with an obvious legitimacy deficit: he was an unelected foreigner whose position stood outside of Bosnia and Herzegovina's constitutional order. Moreover, movement between positions created expectations that required management. As the demands to make Bosnia and Herzegovina a full protectorate showed, being an addressee of Bosnian opinion was not something he could choose. Thus a significant amount of time was spent justifying not only when he could, or should, occupy these positions, but also what it meant to occupy them-to enact sets of relations and define or at least delimit what they could be taken to signify. An analysis of OHR publicity shows that Petritsch discursively created a dividing line between himself as an "international" and the rest of the people of Bosnia and Herzegovina. Yet he also blurred that line by evoking a certain intimacy with Bosnian desires when claiming to act according to the interests of Bosnia and Herzegovina citizens, even when removing 
officials whom those citizens had presumably elected to represent their interests. This points to the HR's use of a discourse of evaluation, through which he sought to create relations of difference between "internationals" and the people(s) of Bosnia and Herzegovina as well as a distribution of agency and responsibility for those categorized as such.

Similar to what Graan noted in his study of post-conflict Macedonia (2010), foreign evaluations of Bosnia and Herzegovina politics and society were distinguished by their pedagogical and paternalistic tone in relation to various Bosnia and Herzegovina publics, a tone that relied, in turn, upon authorizing discourses of liberal democracy and Europe. One effect of these evaluations was to differentiate and structure an unequal relationship between foreigners and Bosnians by presenting the (European) foreign speaker as an expert (on Europe and democracy) capable of rendering judgment and the latter as immature novice still learning (about democracy and what it means to be European).

In addition to producing a hierarchical relationship between "internationals" and Bosnians, foreign evaluations also created democracy and Europe as the unchanging norms against which to measure all developments in Bosnian politics and society. This reinforced the HR's claimed monopoly on the ability to define what democracy and Europe meant. Take the following evaluation, which is part of the case study in constitutional reform that I develop later in this article. In an open letter entitled "A Chance for Republika Srpska," published in the Banja Luka-based magazine Reporter, Petritsch threatened to assert his powers in precisely the ways he refused to in his mild exchange with the intellectuals:

What the Republika Srpska needs is honest and fundamental reform - deeds, not just words. It is clear that in the 7th year of Dayton, the RS is still a nationalistic mono-ethnic structure, an abnormal model of exclusivity where the rule of law has not taken root. Such a community has no place in the Europe of the 21 st century. There are many areas in which the RS authorities can do better in order to genuinely serve their citizens and prove to the outside world that the RS is a legitimate part of Bosnia and Herzegovina, which is trying to live up to the commitments of the Dayton Peace Agreement and the requirements of the modern age.

Constitutional reform provides a unique opportunity for the RS to implement fundamental and positive change and to address the danger of its disappearance. The RS is threatened from the inside because it does not live up to European standards, because it does not treat all its citizens with the evenhandedness they are entitled to expect in a multiethnic Entity ... this is what delegitimises and weakens the RS. But it can prove otherwise. I would also say that this is also a unique opportunity for the RS authorities to demonstrate the essence of ownership, and show that they have the capacity to forge the sort of compromises which are crucial in a multiethnic society such as Bosnia and Herzegovina.

RS citizens, regardless of their ethnic background, want a normal life. They want living standards that correspond to 21st-century Europe. 
Let me make it perfectly clear. Without a serious commitment to constitutional, social, economic, return and human-rights reforms, the RS may face disappearance - the behaviour of its leaders will have rendered the Entity economically and politically unsustainable (OHR 2001d).

Note how this evaluation constructed a distribution of agency and responsibility designed to catalyze action on the part of RS authorities toward a set of specific goals. The role of domestic actors, in this case RS authorities, were presented as primary and active: demonstrating ownership, proving their commitment, and so forth. When it came to political issues classified as domestic, the role of foreign agencies and actors was presented as secondary, passive, and temporary, as supervising or mediating the actions of Bosnia and Herzegovina officials. It was only when the conduct of those officials' failed to conform to their expected role, either through inaction or the wrong action, that the OHR was forced to take an active role; he never initiated it himself. (Note the implicit threat that closed the above letter, or the final quote from his reply to the intellectuals cited at the outset of this article.)

Such a distribution of agency and responsibility allowed Petritsch to frame the exercise of the Bonn powers as necessary but otherwise an exception to the normal order of things. It enabled him to restate the norms of nation-state sovereignty and democratic representation, as well as to distance responsibility for any given state of affairs away from foreign actors and onto Bosnians, and thereby deflect calls for him to act when addressed by members of the Bosnia and Herzegovina population.

Of course, OHR practices of publicity did not happen in a vacuum. In tacking back and forth between authorizing positions, and in deploying the discourses of Europe, democracy, and evaluation, the HR assumed a set of opposing interests that would critique him on any number of grounds.

\section{Competing Recontextualizations}

Even as some Bosnia and Herzegovina politicians addressed Petritsch as a responsible political authority and exhorted him to exercise the Bonn powers toward particular ends, others cited his unelected status as making his actions illegitimate. Bosnia and Herzegovina officials often authorized their own perspectives and actions with the discourse of national self-determination and popular sovereignty; this discourse could be deployed to resist, take up, or re-signify OHR statements and demands depending upon the situation.

Thus OHR publicity was constantly contending with other domestic registers in framing and reframing their own and others' speech and actions in a series of competitive recontextualizations: were the OHR's actions best understood as "neo-colonial" and "anti-Serb," or were they instead "securing democracy" and modeling "European standards"? Was a vote in the RS National Assembly a "vote against Europe" or "protecting the vital national interests of the Serb nation"? In this way, OHR publicity sought to create frameworks 
of reception and interpretation that anticipated others' attempts to frame OHR speech and actions, and provided arguments against these anticipated counterarguments. Although Petritsch's claims to act in the public interest of Bosnia and Herzegovina's population were often fiercely contested, he maintained a robust ability to both force Bosnia and Herzegovina officials to contend with his representations, and to demobilize opposition to his actions by investing his voicings with the threat of the Bonn powers and the reward of international recognition. Whenever he justified the exercise of the Bonn powers as necessary to break some sort of political impasse, the HR also signaled future sanctions if Bosnian speech and conduct failed to meet international expectations.

In addition to discursively stabilizing rather than eliding or denying the ambivalence of his position, OHR publicity also constructed an image of postwar Bosnia and Herzegovina as caught in a transitory temporality, a limited state of exception to the nation-state order of things. By 2000, there was increasing "donor fatigue" on the part of major foreign powers and growing pressure to reduce the expensive international presence in Bosnia and Herzegovina and turn over responsibility for major tasks like running elections to local institutions. This pressure created a sense of urgency about the changes needed to collapse the transitory temporality and make the Bosnia and Herzegovina state work on its own. This, paradoxically, suggested an expansion of the HR's powers of imposition.

It was at this time that a constitutional amendments process came to figure as a key test of the HR's ability to manage and resolve these competing demands. I now turn to a few key episodes in this process in order to track how Petritsch sought to bring the process to a conclusion without imposing amendments, thus showing that his policy of promoting rule of law and "local ownership" was working - that Bosnia and Herzegovina was a Europeanizing, democratizing, Rechtsstaat that did not need foreign supervision. His failure to manage this process successfully, and his eventual decision to impose the constitutional amendments, indicate the limits of publicity as a form of governmentality.

\section{A CONTROVERSIAL COURT DECISION AND (IN)DIRECT GOVERNMENTALITY}

In June 2000, the State Constitutional Court of Bosnia and Herzegovina handed down its partial ruling on a case initiated by Alija Izetbegović in 1998. It became known as the "constitutive peoples" ruling, and it found that the constitutions of Bosnia and Herzegovina's two political entities, the Federation and $\mathrm{RS}$, contained language that undermined the right of the peoples of Bosnia and Herzegovina to full equality. The particular problematic passages said to be in disagreement with the State Constitution (which was created by the Dayton Agreement and had priority over the entity constitutions) centered on the issue of "constitutive peoplehood"-the definition and delineation of "the 
people" whose self-determining capacity was foundational to the state. The ruling focused on Article I of the RS Constitution, which stated that the RS was a "state of the Serb people and of all of its citizens," and grounded the founding of that state in the "natural, inalienable and non-transferable right of the Serb people to self-determination." The Federation Constitution was identified as problematic on a similar basis, particularly the statement that the Federation was made up of "Bosniacs [sic] and Croats as constituent peoples as well as Others."

The plaintiffs had argued that by making Serbs "constitutive" of the RS and Bosniaks and Croats "constitutive" of the Federation, the entity constitutions undermined the meaning and function of the constitutive peoples principle that had been included in the State Constitution and placed "multi-ethnicity" as a foundational principle of all levels of Bosnia and Herzegovina politics. ${ }^{10}$

The stakes were high. Rightly seeing the case as undermining key terms of the separatist Serb state-building project, RS legal experts mounted a vigorous but unsuccessful challenge to the case. The court's ruling thus directly overturned the exclusive claims to self-determination that underwrote Bosnia and Herzegovina's political entities. More importantly, it also ruled that the entity constitutions needed to be changed to ensure that that Bosniaks, Croats, Serbs, and others were "constitutive" in both entities.

As with all common state institutions provided for in the Dayton Agreement, the Constitutional Court's judicial composition itself reflected the "national key" principle of proportional representation, with international oversight. It thus modeled not only the principle it instituted through the constitutive peoples decision (there were two judges from each of the three main ethnic groups and three foreign judges), but also reflected the divisions that the constitutive peoples ruling aimed to overcome because, controversially, the ruling was taken on a 5 to 4 vote: the Bosniak members voted with the three foreign members of the court, and the court's two Serb and two Croat members dissented.

The reaction in the major news outlets came swiftly as political actors sought to frame the decision in the terms of popular sovereignty and threat that underwrote the state projects they advocated. Politicians from the RS, in particular, signaled their hostility to the ruling, asserting their opposition as synonymous with the will of the Serb people, a people whose very existence, they

10 The preamble to the Constitution that was included as Annex 4 of the Dayton Peace Agreement held that Bosnia and Herzegovina was determined by "Bosniacs, Croats, and Serbs as constituent peoples (along with Others)." The full text of the Dayton Agreement can be found here: http:// peacemaker.un.org/sites/peacemaker.un.org/files/BA_951121_DaytonAgreement.pdf. The full text of the partial decision of the Constitutional Court of Bosnia and Herzegovina can be found in English here: http://www.ustavnisud.ba/dokumenti/_en/u-5-98-12209.pdf (both accessed 11 Jan. 2017). 
claimed, was predicated on the existence of the RS as a mono-ethnic political unit. On a page in the Sarajevo daily Oslobodjenje dedicated to discussing the decision (5 July 2000: 5), RS President Mirko Šarović pointed to the split nature of the court's decision and argued that the decision amounted to the political will of two whole nations being "outvoted," an outrage assisted by the international community. Former RS President (and later convicted war criminal) Biljana Plavšić echoed this sentiment, stating that the decision was "reminiscent of events in 1992 ... when a whole people (Bosnian Serbs) did not take part in the referendum in which Bosnia and Herzegovina was voted out of the former Yugoslavia." She suggested that this decision represented a revision of the Dayton Agreement and could lead to the abolishment of the $\mathrm{RS}$ and thus further violent conflict. This set of positions laid the basis for RS officials to basically ignore the ruling's requirement to amend the RS constitution.

The response of the OHR was at first minimal. On the date of the decision, and reflecting Petritsch's stated interest in building a functioning state based upon the rule of law, he issued a press release that framed the issue in procedural terms, noting that the court's decision was binding (OHR 2000b). However, in response to statements like those quoted above, the OHR issued a scolding, paternalistic press release in a bid to police the political speech of domestic officials (OHR 2000c).

Aside from these initial press releases, the OHR was relatively silent, noting occasionally that constitutional reform was one of many issues that needed attention after the country-wide elections took place in the fall. Yet in the two months following the elections of November 2000, aside from the formal creation of otherwise moribund constitutional commissions in the entity parliamentary assemblies, nothing happened to bring the entity constitutions in line with the court's ruling. Thus in January 2001, seven months after the initial ruling of the court, Petritsch exercised his powers in a novel way: he issued a decision in order to incite an enactment of "local ownership" over political processes.

The decision essentially recreated the constitutional commissions in each entity and required them to prepare recommendations for the implementation of the Constitutional Court decision within two months (OHR 2001a). As with other decisions, Petritsch argued in the preamble that he was compelled to act in order to overcome an impasse created by politicians who were failing to respond to the court's ruling. He also claimed to be acting to protect all of Bosnia and Herzegovina's citizens against the discrimination that existed in the absence of constitutional reform.

The decision and its justification embodied an ambivalent logic: it invoked democratic values like the rule of law and involved actors with democratic legitimacy, but it was imposed by an unelected official. The HR declared that each commission would have sixteen members, chosen by him from 
among those elected to sit in the entity assemblies. He emphasized that the creation of these commissions and his assertion over their form and composition were not to be construed as dictating "the way in which the said partial Decision of the Constitutional Court shall be implemented." That was to be decided by Bosnia and Herzegovina officials, not foreigners. He also stressed that foreign intervention into constitutional matters was of a temporary, "interim" and isolated nature. In other words, he went to great pains to cast his role as passively mediating, rather than actively dictating. It was the first time that he exercised the Bonn powers in this way, to initiate a governmental process and compose a group of people to carry out the process. Of course, in order for constitutional reform to be a convincing enactment of "local ownership," it required the active participation of Bosnia and Herzegovina officials - neither participation nor the end result could be imposed.

The existence of the Bonn powers framed the way in which Bosnia and Herzegovina authorities calculated risks and benefits to cooperating with international expectations. The benefits included financial resources and the kind of domestic political capital that came with international recognition. This was clearly the calculation of the Alliance for Change, a disparate collection of nonnationalist parties that had ruled in the Federation and state government since 2000 under the visible sponsorship of key foreign powers. The risks to going against international expectations had been demonstrated by past removals of politicians from office.

But the hazards of cooperation were also present. In this case, the constitutional reform process threatened to erode a core foundation of legitimacy for RS politicians, who had thus far taken the process as an opportunity to enact their own ongoing performance of national self-determination by criticizing and then ignoring the court ruling. Publicity was one of the sites and instruments through which these benefits and hazards were negotiated, as became clear in the end-game of the amendments process that played out over the first few months of 2002 .

\section{THE STAKES ARE RAISED}

Despite the hope that his January 2001 decision would see the amendments outlined and adopted in a swift manner, by year's end no visible progress had been made. With the end of his term as HR just half a year away, the issue came to be seen by Petritsch as a referendum on his tenure, and toward the end of 2001 he sought to catalyze action on the amendments process.

One example was the letter "A Chance for Republika Srpska" (excerpted above), which was the conclusion of a series of actions and pronouncements that focused attention on the RS as the source of obstruction to progress on numerous fronts, including the amendments process. In interviews and press conferences, Petritsch threatened sanctions while relentlessly criticizing RS 
officials for risking isolation from Europe and not following the rule of law. He also sought to contain a familiar counterargument:

In my discussions with RS officials, I often hear the argument that this or that cannot be done because "the people" are against it. Firstly, I do not believe this. "The people's will" is often used as a convenient excuse for obstructionism that is in the sole interest of officials who want to protect their personal interests. Take, for example, the neutral license plates. When we negotiated them in 1997, RS leaders such as Krajisnik predicted violence and demonstrations by "the people." As it turned out, "the people" was eagerly queuing up for the new plates once they were launched (OHR 2001c).

It was in this context that in late January 2002 leaders from the eight largest political parties from both entities met at Mrakovica in the Kozara mountains to discuss the amendments, and significant agreement was reached. However, when little progress was made afterward on a few sticking points, and stating that his role was only to "facilitate and mediate," Petritsch hosted what his office called Bosnia's "tryst with destiny" (OHR 2002a), a seventy-hour marathon round of negotiation between the leaders of the eight parties. In an effort to frame this as an exercise in "local ownership" of state political processes, photos of the meetings were made available to the press and showed party leaders (and Petritsch) in various scenes, "working together," "in negotiation," and even laughing. At the press conference announcing the conclusions of the negotiation, photos show Petritsch at a podium, surrounded by the party representatives. Whether these images show him as a leader or a mere mediator is unclear.

As a result of this marathon session, most of the major parties in each entity signed what became known as the Mrakovica-Sarajevo Agreement on "mutually acceptable principles and provisions." Petritsch, the U.S. Ambassador, and the Spanish Ambassador (representing the EU) signed as witnesses. These principles had to be concretized in the recommendations of the entity constitutional commissions and then presented to the respective entity assemblies to be voted upon. In the RS, this process did not play out as the OHR hoped for, and it found itself outmaneuvered and bumping up against the limits of its "ownership" strategy.

\section{“OUTVOTING" AND THE RSNA AMENDMENTS}

Almost immediately upon returning to Banja Luka, representatives from the RS publicly played down the binding nature of the Mrakovica-Sarajevo agreement, instead calling it a good starting point for discussion. Having gained international recognition and restated their status as indispensable players in Bosnian politics, they now sought to prevent appearing to have undermined the Serb state project by presenting themselves as having contained the potential damage to the RS (International Crisis Group 2002: 8). They also made 
pronouncements that signaled their continuing opposition to the court's decision, even while claiming they were complying with it.

In the days between the signing of the Mrakovica-Sarajevo agreement and the session in which the RS National Assembly (RSNA) was to vote on the amendments, the Bosnian media was full of assessments by RS politicians and their supporters about what effect the amendments would have on the future of the RS. Important justification for resisting the Mrakovica-Sarajevo Agreement was provided publicly by Serb members of the State Constitutional Court. In an issue of Glas Srpski, court member Vitomir Popović argued that the principles in the agreement and the corresponding constitutional amendments could have dire economic consequences: "Probably, they will be accompanied by demands to abolish the hymn, flag, coat of arms, and all [state] characteristics of the RS.... Besides that, a large number of our people will be left without work in all state and public structures" (Glas Srpski, 4 Apr. 2002).

Casting this issue as a potential repeat of the "oppression" against Bosnian Serbs by Bosnian Croats and Bosniaks was clearest in the deployment of the discourse of "outvoting." On one newspaper's opinion page, a member of the RSNA Constitutional Commission, Branko Morait, delegitimized the commission's recommendations by repeating an argument associated with the lead-up to the 1990s war. At that time, Serb nationalist politicians claimed that two of Bosnia's peoples (Croats and Muslims) had "outvoted" the Serb people when deciding the question of Bosnia's independence; Morait argued that the amendments process was threatening to repeat this violation of the "will of the Serb people" and could thus lead to a repeat of the violence of the war (Nezavisne Novine, 4 Apr. 2002).

News media also reported upon a set of meetings between RS governmental authorities and representatives of Bosnian Serb military veterans. Veteran representatives claimed that the Mrakovica-Sarajevo Agreement dishonored the blood spilt in "the centuries-long struggle of the Serb people for freedom and state independence" (Glas Srpski, 2 Apr. 2002). They characterized the agreement in terms that cast Muslims as battlefield enemies and argued that it was not the result of "compromise" by Serb, Muslim, and Croat political parties but was rather an imposition of the international community. After meeting with veteran representatives, the Speaker of the RSNA, Dragan Kalinić, noted that they disagreed with the agreement "offered by the High Representative" and vowed that they would never allow the disappearance of the RS.

Having publicly laid the basis for resisting the amendments process as an undemocratic imposition of hostile Bosniaks and their foreign allies, and having sacralized this resistance with the invocation of the blood spilt by Serbs in the 1990s war, the stage was set. In the legislative session on 4 April, convened in the RSNA for the specific purpose of debating and then 
adopting the provisions of the Mrakovica-Sarajevo Agreement, the Speaker exploited a procedural loophole to propose an alternative set of amendments, drawn up in secret and signed by all sixty-eight Serb deputies (82 percent of all deputies in the RSNA). The alternative set departed significantly from the Mrakovica-Sarajevo Agreement, and even appeared to violate the Dayton Agreement in the very terms struck down by the Constitutional Court decision (International Crisis Group 2002: 12). In doing so, the majority in the RSNA demonstrated their unwillingness to go along with the expectations created by the OHR's managed process or with the Constitutional Court's decision. When the RSNA constitutional commission rejected the alternative amendments (as had been expected), it triggered a procedure whereby both the constitutional commission's draft amendments and the new alternatives came up for a vote and the latter passed without discussion, despite attempts by non-Serb deputies to postpone and then later to disrupt the vote.

The RS political leadership had, in other words, used an internationally instigated event of democracy-at-work and local ownership to orchestrate a performance of resistance and collective Serb self-determination. Afterward, various RS party leaders publicly cast themselves as having fended off an attack on their state project, as peacemakers for having avoided the violence that such an attack would have inaugurated if it had succeeded, and as having mitigated the anti-European accusations of the "international community" (ibid.: 9).

The strategy of the HR to use publicity in tandem with the Bonn powers lay in tatters. One of the governing parties in the Federation which had wholeheartedly supported the Mrakovica-Sarajevo Agreement publicly threatened to withdraw its commitment to it if the HR did nothing about the amendments passed by the RSNA (ibid.: 11). Emboldened by the RNSA vote, Bosniak and Croat nationalist parties in the Federation House of Representatives opposed the amendments and thus prevented them from passing in that entity as well. On 11 April, Petritsch publicly responded to calls that he take action by stating that the international community wanted only a mediating and not an implementing role (Nezavisne Novine, 11 Apr. 2002).

Such statements notwithstanding, a series of events, all conspicuously documented and circulated in OHR press releases, made it clear that plans were underway to impose the amendments. As a signatory and thus selfdescribed "guarantor" of the Mrakovica-Sarajevo Agreement, Petritsch issued a deadline of 18 April for it to be fulfilled by both the Federation and RS legislative bodies. On 10 April, he consulted with the Steering Board of the Peace Implementation Council, which gave him their full backing. Two days later, the ambassadors of the United States, United Kingdom, Germany, Italy, and France conveyed to the four party representatives of the RS that the RSNA amendments did not fulfill the Mrakovica-Sarajevo Agreement. On 19 April, Petritsch was forced to do what he had spent nearly two years 
avoiding: he imposed the Mrakovica-Sarajevo Agreement amendments upon the RS and the Federation constitutions (OHR 2002b).

\section{CONCLUSION}

To some degree, the failure of internationally mediated constitutional reform to deliver a convincing performance of "local ownership" over state processes was rooted in an instability created by the Dayton Agreement, particularly its partial recognition and cobbling together of multiple state projects. The end goal of "democratization" and "local ownership" of the state faltered when the "locals" disputed what state it was they were demonstrating ownership over and in which they were to enact democratic relations of representation and accountability. This was particularly the case here because in demonstrating "ownership" local politicians were required to undermine a core basis for their authority, which was a commitment to a state project that embodied Serb national self-determination.

This instability is the result, in part, of the UN order of nation-states in which Bosnia exists, an order committed to steady state existence, where nation-states cannot (legally) expand their territory and in which all warfare between nations and states, especially wars of conquest, is outlawed. Thus once Bosnia and Herzegovina had gained international recognition as an independent state, the international response to the war in Bosnia and Herzegovina (and ethnic conflict in Kosovo and sectarian violence in Iraq) was international "state-building" under the sign of democracy, where "the people" are supposed to be sovereign. This put the HR in postwar Bosnia and Herzegovina in a tricky position as an unelected foreigner pursuing state-building and democratization goals in a context of unfinished state projects, where internationals and locals alike sought to ground their authority in some definition of "the people." What I have shown here are some of the innovations through which the HR sought to legitimately pursue these goals in the face of two contradictions-what I have called the democratization and state-building paradoxes.

Publicity was indispensable to this task: it was an instrument to invoke the "international community" as a source of authority; to conjure and contest the authorizing abstractions of democracy and popular sovereignty-the people and its will, public opinion, and so forth; to enact relations of representation and accountability; to define a distribution of responsibility in relation to political action; to proliferate normative understandings of democracy and nationstate sovereignty even while violating those norms; and to exercise symbolic authority by circulating and attempting to monopolize the authorizing discourses of democracy and Europe. It was also a means of governmentality used to incite actions along prescribed pathways. By focusing on the OHR's practices of publicity, I have uncovered a political logic of ambivalence and outlined its advantages and limits as a framework for transformation. By showing the performative and dialogic nature of OHR speech and action, I 
restore some sense of the volatility and unpredictability of the intervention encounter.

This leads me to question the easy conclusions behind some of the most common critiques of international intervention. One explanation for why publicity has been overlooked in studies of intervention lies in how scholars and commentators have related their critique to the paradoxes and contradictions of international intervention. Indeed, most critical writing uses a discourse of (neo)colonialism or (neo)imperialism, taking the twin paradoxes that I detail in this article as the endpoint of analysis and beginning of critique. Yet, as Cooper and Burbank (2012: 239) have noted, those evoking the language of empire are often more interested in discrediting, praising, or otherwise influencing such intervention projects and their government sponsors than with understanding what is unfolding on the ground (Chandler 2006; Ignatieff 2003; Knaus and Martin 2003). Such critiques are inherently normative, relying upon the categorical distinctions of nation-state order and its forms of popular sovereignty for their description of "foreign" domination over "domestic" populations. They are thus likely to look past instances like the opening vignette about a Bosnian desire for the suspension of ostensibly democratic institutions and duly elected representatives because they do not easily fit the narrative of (neo)imperial domination. Such forms of critique entail categorical and normative assumptions about how "democracy" and "the state" should function and quickly conclude that Petritsch's rejection of international responsibility for Bosnian politics must be an instance of "empire in denial" (Chandler 2006), a rhetorical smokescreen or psychological blind spot that renders the exercise of power unaccountable. To focus on paradox or contradiction in this way is to hurry to the ought rather than to dwell with the is. I suggest here that rather than taking contradiction and paradox as the motor-engine of a normative critique (and thus the end of the story of how to understand international intervention), we should see them as the motor-engine of pragmatic action - that is, the beginning of an account of international intervention. After all, it is in confronting and managing these contradictions that the actual politics of intervention unfold.

This analysis thus suggests that any study of international state- or nationbuilding, or democratization, should include attention to practices of publicity. Indeed, a brief examination of the on-line archives of press releases from the Iraq Coalition Provisional Authority and of the Daily Briefings of the UN Transitional Administration of East Timor ${ }^{11}$ reveals rich repositories of political communication and governmentality centered on challenges of authority and legitimacy similar to those faced by the OHR.

\footnotetext{
11 See http://www.iraqcoalition.org/pressreleases/ and http://www.un.org/en/peacekeeping/missions/ past/etimor/DB/UntaetDB.htm (both accessed 3 Nov. 2015).
} 
One thing all post-Cold War interventions share is a stated commitment to the temporary nature of foreign administration (Zaum 2012). The production of a time-space of suspension is not uncommon in arguments that seek to legitimize relations of rule on the grounds of necessary transformation. As Chakrabarty reminds us, imperial warrants to rule were based upon claims that "some historical time of development and civilization (colonial rule and education to be precise) had to pass" before colonized peoples were ready for self-rule, and this consigned the colonies to an "imaginary waiting room of history" (2000: 8), always caught up in a temporality of "not yet." Povinelli (2011) noted the "temporal structure of limbo" that underwrote a settler-state program to transform Aboriginal life in late liberal Australia, in which the hardship and suffering instigated by the Intervention (as it was called) was discursively and ethically bracketed in the present, and legitimized as a necessary sacrifice when measured from the perspective of a future in which the transformation will have been completed.

The transitory temporality constructed by OHR publicity shared qualities with both of these contexts: the paternalistic tone and the vocabulary of deficiency inherent in much foreign evaluation are strongly reminiscent of justification for imperial relations of rule. And like Povinelli's case, the means/ends contradictions of the OHR's use of the Bonn powers were not so much to be overcome or resolved as to simply disappear. Once transformation had taken place, the OHR's position would be obsolete and the contradictions would disappear with the OHR.

But such "states of exception" and transitory temporalities are achievements, produced by practices that include their own instabilities and performative requirements. Moreover, in a point mostly overlooked in the critical literature, once states of exception are posited and brought into being, they can be hard to undo. Petritsch needed the participation of elected politicians as the normative representatives of the popular will in state government for the performances of local ownership and democracy-at-work. If successful, such performances would demonstrate that Bosnia and Herzegovina was a state that could work on its own and permit the withdrawal of the international community and collapse the state of exception. His stick was the Bonn powers and other forms of international disapproval, and his carrot was international recognition, financial resources, and the promise of "joining Europe."

Some Bosnian politicians, however, decided that dwelling in such limbo had its advantages, and they worked within it to create a distribution of political responsibility to their own benefit. Under these conditions they participated enough to gain or maintain recognition as indispensable players in Bosnian politics. When participation threatened their base of authority or power, however, they could and did refuse to cooperate and instead cast themselves as defenders of the popular will and national self-determination against foreign oppressors or the state projects of hostile ethnic Others. Particularly if they knew that the HR 
was ready to impose laws or reforms likely to be unpopular or threaten their base of power, they had much to gain by orchestrating performances of resistance that restated their authority through opposition (see Toal 2013, for a recent example). ${ }^{12}$ This deflected or demoted other ways of measuring governmental legitimacy, such as the degree to which Bosnia and Herzegovina authorities fulfilled the biopolitical responsibilities for the health and wellbeing of the population. And such conditions worked to keep the question of state form and thus the temporality of transition open, despite attempts to bring it to a close. Each collapsed internationally supervised effort, and each exercise of the Bonn powers, was a restatement of the need for an international presence and the value of ambivalence. This case study describes a combination of disciplinary and governmental power (which often coexist, as Foucault noted) that may be mutually limiting. In Bosnia and Herzegovina, the logic of ambivalence helped to produce a political condition of stalemate.

But this could not go on indefinitely. In important ways, to declare a state of exception is to maintain a norm. In postwar Bosnia, the way in which the OHR used publicity to produce this state of exception contained its own eroding condition as a position of legitimacy and thus shrinking temporal horizon as grounds for action, since to maintain norms in this way was to draw attention to their violation. Indeed, although the position of HR remains in Bosnia and Herzegovina at the time of this writing, and the OHR continues to be an active presence in Bosnia's public sphere, the exercise of the Bonn powers has basically ceased. Since 2009 the few decisions that have issued from the OHR have been to terminate, repeal, or suspend the application of earlier decisions. Ambivalence had become unsustainable.

REFERENCES

Agamben, Giorgio. 2005. State of Exception. Kevin Attell, trans. Chicago: University of Chicago Press.

Ahmetašević, Nidžara. 2012. Intervening in the Media Sector: Media Anarchy in postwar Bosnia and Herzegovina. Uni Graz Working Paper 6 (Dec). Graz: Centre for Southeast European Studies.

Anderson, Benedict. 1991. Imagined Communities: Reflections on the Origins and Spread of Nationalism. New York: Verso.

Bialasiewicz, Luisa et al. 2007. Performing Security: The Imaginative Geographies of Current US Strategy. Political Geography 26: 405-22.

Borneman, John. 2003. Responsibility after Military Intervention: What Is Regime Change? PoLAR: Political and Legal Anthropology Review 26, 1: 29-42.

Bourdieu, Pierre. 1991. Language and Symbolic Power. Cambridge: Harvard University Press.

12 There were limits to such resistance, such as when, in early 2001, the HR and foreign military and police forces mobilized to put down a Croat nationalist-organized boycott of Federation institutions, and the creation of parallel institutions of government. 
Chakrabarty, Dipesh. 2000. Provincializing Europe: Postcolonial Thought and Historical Difference. Princeton: Princeton University Press.

Chandler, David. 2006. Empire in Denial: The Politics of State-Building. London: Pluto Press.

Cooper, Frederick and Jane Burbank. 2012. The Empire Effect. Public Culture 24, 2 : 239-47.

Cowan, Jane. 2007. The Supervised State. Identities: Global Studies in Power and History 14: 545-78.

Dodds, Klaus. 1996. The 1982 Falklands War and a Critical Geopolitical Eye: Steve Bell and the if ... Cartoons. Political Geography 15, 6-7: 571-92.

Dodds, Klaus and Sean Carter. 2014. International Politics and Film. New York: Columbia University Press.

Duffield, Mark. 2007. Development, Security, and Unending War: Governing the World of Peoples. Cambridge: Polity Press.

Foucault, Michel. 2002. Power: Essential Works of Foucault 1954-1984. Vol. 3. James D. Faubion, ed., Robert Hurley, trans. London: Penguin.

Fraser, Nancy. 2007. Transnationalizing the Public Sphere: On the Legitimacy and Efficacy of Public Opinion in a Post-Westphalian World. Theory, Culture \& Society 24, 4: 7-30.

Gilbert, Andrew. 2012. Legitimacy Matters: Managing the Democratization Paradox of Foreign State-Building in Bosnia and Herzegovina. Südosteuropa 60, 4: 483-96.

Graan, Andrew. 2010. Watching the World Watch: News Media and the Everyday Politics of International Oversight in Post-Conflict Macedonia. PhD diss., Department of Anthropology, University of Chicago.

Graan, Andrew. 2016. Strategic Publicity: On International Intervention and the Performativity of Public Communication in Postconflict Macedonia. HAU: Journal of Ethnographic Theory 6, 3: 277-303.

Gregory, Derek. 2004. The Colonial Present: Afghanistan, Palestine, Iraq. Oxford: Wiley-Blackwell.

Habermas, Jurgen. 1989. Structural Transformation of the Public Sphere: An Inquiry into a Category of Bourgeois Society. Cambridge: MIT Press.

Heathershaw, John. 2012. Neither Built nor Formed: The Transformation of PostConflict States under International Intervention. In Berit Bliesemann de Guevara, ed., Statebuilding and State-Formation: The Political Sociology of Intervention. New York: Routledge. 246-59.

Higate, Paul and Marsha Henry. 2009. Insecure Spaces: Peacekeeping, Power, and Performance in Haiti, Kosovo and Liberia. London: Zed Books.

Howland, Douglas and Luise White, eds. 2009. Introduction: Sovereignty and the Study of States. In Douglas Howland and Luise White, eds., The State of Sovereignty: Territories, Laws, Populations. Bloomington: Indiana University Press, 1-18.

Ignatieff, Michael. 2003. Empire Lite: Nation-Building in Bosnia, Kosovo, Afghanistan. London: Vintage.

Inda, Jonathan Xavier. 2005. Analytics of the Modern: An Introduction. In Jonathan Xavier Inda, ed., Anthropologies of Modernity: Foucault, Government, and Life Politics. Malden: Blackwell, 1-22.

International Crisis Group. 2002. Implementing Equality: The "Constituent Peoples" Decision in Bosnia and Herzegovina." Balkans Report 128. Sarajevo/Brussels: International Crisis Group.

Jeffrey, Alex. 2013. The Improvised State: Sovereignty, Performance, and Agency in Dayton Bosnia. Malden: Wiley \& Sons. 
Kelly, John D. and Martha Kaplan. 2009. Legal Fictions after Empire. In Douglas Howland and Luise White, eds., The State of Sovereignty: Territories, Laws, Populations. Bloomington: Indiana University Press, 169-95.

Knaus Gerald and Felix Martin. 2003. Travails of the European Raj. Journal of Democracy 14, 3: 60-74.

Majstorović, Danijela. 2007. Construction of Europeanization in the High Representative's Discourse in Bosnia and Herzegovina. Discourse and Society 18, 5: 627-51.

Office of the High Representative (OHR). 1999. New Year's Letter by the High Representative to the Citizens of Bosnia and Herzegovina: Can Bosnia and Herzegovina and Europe Work as One? Press release, 31 Dec.: http://www.ohr.int/?p=54318 (accessed 11 Jan. 2017).

Office of the High Representative (OHR). 2000a. The High Representative Discusses Protectorate in Dani. Press release, 3 Mar.: http://www.ohr.int/?p=57099 (accessed 11 Jan. 2017).

Office of the High Representative (OHR). 2000b. Decision by the Bosnia and Herzegovina Constitutional Court. Press release, 4 July: http://www.ohr.int/?p=56755 (accessed 11 Jan. 2017).

Office of the High Representative (OHR). 2000c. The High Representative Calls for Moderation in the Discussion of the Constitutional Court Decision. Press release, 7 July: http://www.ohr.int/?p=56743 (accessed 11 Jan. 2017).

Office of the High Representative (OHR). 2000d. Speech by the High Representative, Wolfgang Petritsch, to "Circle 99." Speeches, 2 Nov.: http://www.ohr.int/?p=57811 (accessed 11 Jan. 2017).

Office of the High Representative (OHR). 2000e. An Open Letter to the Pensioners of Bosnia and Herzegovina from the High Representative. Press release, 5 Dec.: http:// www.ohr.int/?p=56431 (accessed 11 Jan. 2017).

Office of the High Representative (OHR). 2000f. High Representative's New Year's Message to the Citizens of Bosnia and Herzegovina. Press release, 29 Dec.: http:// www.ohr.int/?p=56351 (accessed 11 Jan. 2017).

Office of the High Representative (OHR). 2001a. Decision Establishing Interim Procedures to Protect Vital Interests of Constituent Peoples and Others, Including Freedom from Discrimination. Decision, 11 Jan.: http://www.ohr.int/?p=67112 (accessed 11 Jan. 2017).

Office of the High Representative (OHR). 2001b. The High Representative's Press Conference on the Dismissal of HDZ Officials. Press conference, 7 Mar.: http://www.ohr. int/?p=57947 (accessed 11 Jan. 2017).

Office of the High Representative (OHR). 2001c. Enough of Lies. In Reporter (Banja Luka), 12 Nov.: http://www.ohr.int/?p=53345 (accessed 11 Jan. 2017).

Office of the High Representative (OHR). 2001d. A Chance for the Republika Srpska. Interviews/Articles. In Reporter (Banja Luka), 25 Dec.: http://www.ohr.int/?p=52961 (accessed 11 Jan. 2017).

Office of the High Representative (OHR). 2002a. On the Eve of Final Talks, the High Representative Presses Bosnia and Herzegovina's Leaders for a Domestic Solution. Press release, 24 Mar.: http://www.ohr.int/?p=52117 (accessed 11 Jan. 2017).

Office of the High Representative (OHR). 2002b. Press Conference of the High Representative, Wolfgang Petritsch, on the Completion of the Constitutional Reform Process in Bosnia and Herzegovina's Entities. Press conference, 19 Apr:: http:// www.ohr.int/?p=51769 (accessed 11 Jan. 2017).

Office of the High Representative (OHR). 2002c. High Representative Removes Nikola Grabovac. Press release, 14 June: http://www.ohr.int/?p=51085 (accessed 11 Jan. 2017). 
Office of the High Representative (OHR). 2003. Parliament Failing Europe's Test. Press release, 16 Oct.: http://www.ohr.int/?p=47343 (accessed 11 Jan. 2017).

Paris, Roland and Timothy D. Sisk. 2007. Managing Contradictions: The Inherent Dilemmas of Postwar State-Building. New York: International Peace Academy.

Peace Implementation Council. 1997. Bonn Conclusions. Dec. 12: http://www.ohr.int/? $\mathrm{p}=54137$ (accessed 11 Jan. 2017).

Pečanin, Senad, Ivan Lovrenović, Mile Stojić, and Nerzuk Ćurak. 2000. Deset teza za Bosnu i Hercegovinu [Ten theses for Bosnia and Herzegovina]. Dani 139 (28 Jan.): 16-17.

Povinelli, Elizabeth. 2011. Economies of Abandonment: Social Belonging and Endurances in Late Liberalism. Durham: Duke University Press.

Price, Monroe E. 2002. Bosnia-Hercegovina and Post-Conflict Media Restructuring. In Monroe E. Price, Beata Rozumilowicz, and Stefaan G. Verhulst, eds., Media Reform: Democratizing the Media, Democratizing the State. New York: Routledge, 89-106.

Robison, Bridget. 2004. Putting Bosnia in Its Place: Critical Geopolitics and the Representation of Bosnia in the British Print Media. Geopolitics 9, 2: 378-401.

Rose, Nikolas and Peter Miller. 1992. Political Power beyond the State: Problematics of Government. British Journal of Sociology 43, 2: 173-205.

Toal, Gerard. 2013. "Republika Srpska will have a referendum": The Rhetorical Politics of Milorad Dodik. Nationalities Papers 41, 1: 166-204.

Toal, Gerard and Carl Dahlman. 2011. Bosnia Remade: Ethnic Cleansing and Its Reversal. New York: Oxford University Press.

Zaum, Dominik. 2012. Exit and International Administrations. In Richard Caplan, ed., Exit Strategies and State Building. New York: Oxford University Press. 137-58. 
Abstract: This article explores the ambivalent forms of authority and legitimacy articulated by the Office of the High Representative of the international community in postwar Bosnia and Herzegovina. The High Representative exercised quasi-sovereign powers that placed his position at the center of two contradictions: a democratization paradox of "imposing democracy," that is, promoting democracy through undemocratic means, and a state-building paradox of building an independent state by violating the principle of popular sovereignty. I analyze the Office's use of mass-mediated publicity to show how the High Representative sought to legitimize his actions in ways that both sustained the norms of democracy and statehood he advocated and suspended the contradictions behind how he promoted them. In doing so, he claimed that Bosnia was caught in a temporary state of exception to the normal nation-state order of things. This claim obliged him to show that he was working to end the state of exception. By focusing on one failed attempt by the OHR to orchestrate an enactment of "local ownership" that was aimed at demonstrating that Bosnia no longer required foreign supervision, this article identifies important limits to internationally instigated political transformation. It offers a view of international intervention that is more volatile, open-ended, and unpredictable than either the ordered representations of the technocratic vision or the confident assertions that critique international intervention as a form of (neo)imperial domination. It also demonstrates the analytic importance of publicity for the comparative study of international nation-building and democratization in the post-Cold War era.

Key words: international intervention, public sphere, mass media, state-building, democratization, state of exception, Bosnia and Herzegovina 